\title{
Analysis of Implementation of Standards for Facilities and Infrastructure of State Aliyah Madrasah in Medan City Based Minister of National Education Regulation Number of 2007
}

\author{
Lia Khairia Harahap ${ }^{1}$, Ibnu Hajar², Arif Rahman ${ }^{3}$ \\ Master of Education Administration, State University of Medan, Indonesia ${ }^{1}$, \\ Lectures of Education Administration, State University of Medan, Indonesia ${ }^{2,3}$ \\ khairia922@gmail.com
}

\begin{abstract}
The Minister of National Education Regulation Number 24/2007 is a policy regarding educational facilities and infrastructure standards. State Aliyah Madrasah facilities and infrastructure in Medan are available in the appropriate category. This study focuses on how the Minister of National Education Regulation Number 24/2007 conducted by Madrasah Aliyah Negara Kota in Medan. Data analysis uses the theory put forward by George C. Edward III regarding policy implementation. This research is qualitative with data collection techniques through interviews, document reviews, observations, and making field notes. The results of this study explain that the implementation of Minister of National Education Regulation Number 24 of 2007 has been carried out since 2009. Implementation of Minister of National Education Regulation Number 24 of 2007 carried out by state madrasas in Medan. can not be separated from the role of the Regional Office of the Department of Religion of North Sumatra Province through the Madrasas Education Sector facilities and infrastructure section. In the technical implementation of the regulation, there is work synergy between the Madrasah Education Sector, facilities and infrastructure section of the Office of the Ministry of Religion, North Sumatra Province and the Aliyah Madrasah State in Medan. This synergy can be seen from the activities of training guidance, workshops, coordination, and work meetings between work units to build a shared vision and mission.
\end{abstract}

Keywords: Policy Implementation, National Education Regulation Number 24 of 2007, State Aliyah Madrasah in Medan City

\section{Introduction}

The Minister of National Education Regulation Number 24/2007 is a standard provision of facilities and infrastructure that is a reference for every formal education institution (school) in Indonesia. Every educational institution is required to make available educational facilities in accordance with these regulatory standards. Through this regulation, it is expected that there will be an even distribution of quality of education, particularly in terms of the availability of facilities and infrastructure, in every region in Indonesia. Based on The Minister of National Education Regulation Number 24/2007, the facilities and infrastructure to support the learning 
of Madrasah Aliyah Negeri (MAN) in Medan have been available in the category of good condition and are ready to be operational. This condition can be seen from the presence of modern buildings and equipment, such as laboratories and teaching aids (language, biology, physics, computers, chemistry), mosque, UKS room, library room. In addition there are several infrastructures that support extracurricular activities, including: Da'wah cadre courses, scouts, marching bands, paskibra, PMR (youth red cross), youth scientific works, nasyid groups, regional dances, green madrasas, English clubs, sports extracurricular (such as volleyball, table tennis, badminton, basketball and futsal), sismantap (anti-drug madrasa students). Based on these data, the focus of the discussion in this paper is how is the implementation of Goverment regulation No. 24 of 2007 regarding facilities and infrastructure carried out Madrasah Aliyah in Medan City.

The theory used in referring to the grand theory proposed by George C. Edward III, which states that the process of policy implementation has 4 important variables that are interconnected with one another. The four variables are communication, resources, disposition, and bureaucratic structure [1]. The relationship between the four variables on the results of implementation can be explained as follows:

a) Communication; is the process of delivering policies from policy makers to policy implementers. There are three things in this communication that need attention: (1) Transmission; model or method of delivering policies from policy makers to policy implementers. (2) Clarity; The submitted policy must be clear and not confusing or ambiguous.

(3) Consistency; policies must be consistent, not changeable, which can confuse the implementer.

b) Resources; resources relating to all resources that can be used fatherly to support the successful implementation of a policy, both physical resources, such as the Implementer (implementer), facilities goods / equipment and non-physical resources, such as, access to information, authority.

c) Disposition or attitudes; is the attitude of the will or desire and commitment of the implementer towards the implementation of the policy. Disposition requires two things, namely staffing, staffing and intensive giving.

d) Bureaucratic structure; with regard to the mechanism of work in a bureaucracy relating to Standard Operating Procedures (SOP) and the division of work responsibilities in work units.

So, based on the explanation above, the factors of communication, resources, disposition, and bureaucratic structure influence the degree of success of policy implementation. Each of these factors interacts with and influence one another, which in turn influences policy implementation. Regarding the form of interaction between the four factors that influence the implementation of this policy can be seen in Figure 1: 


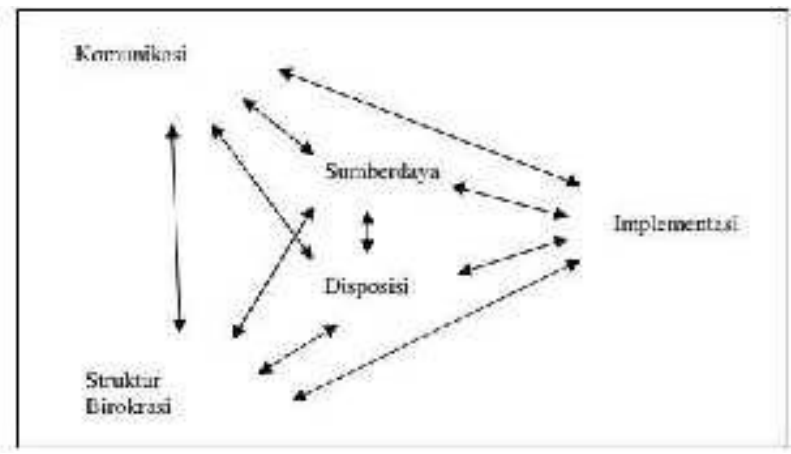

Fig 1: George C. Edwards III Model Chart [2]

\section{Research Methods}

This research was conducted using qualitative research methods, which are classified as field research (Field Research). To achieve the expected data in this study, the authors use several data collection techniques such as those used by Lincoln and Guba, namely using interviews, and reviewing documents (records or archives) that support and complement each other in fulfilling the required data as research focus. In addition, other data collection techniques that have been done by the author is by doing observation and making a field note when doing research. To check the validity of the data obtained in this study, researchers used the Triangulation technique developed by Lincoln and Guba, which consisted of: credibility, transferability, dependability, confirm ability. While the data analysis model used refers to the data analysis of the Miles and Huberman model [3], including: data reduction, data presentation.

\section{Results and Discussion}

In implementing the Regulation of the Minister of National Education of Republic of Indonesia Number 24 of 2007 Concerned on the Facilities and Infrastructure Standards of Elementary Schools/Madrasah Ibtidaiyah (SD/MI), First High Schools/ Madrasah Tsanawiyah (SMP/MTs), and Middle Schools/Madrasah Aliyah (SMA/MA) cannot be separated from the role of the Regional Office of the Ministry of Religion of North Sumatra Province (hereinafter abbreviated as the North Sumatra Ministry of Religion) through the facilities and infrastructure of Madrasah Education Sector as the parent of religious education institutions at the district / city level. Because basically the North Sumatra Ministry of Religion in the field of madrasa education is responsible for efforts to improve the quality and quality of madrassas under its auspices, including those related to facilities and infrastructure. 


\section{a) Transmission / Delivery of Messages}

In the Implementation of government regulation no. 24 of 2007 concerning facilities and infrastructure, the North Sumatra Ministry of Religion through the madrasah education sector conveyed the technical implementation of the policy to the heads or Vice principal III in the area of madrasah facilities and infrastructure carried out by means of socialization, workshops and training of the Technical Guidance and meetings of leadership leaders madrasa. Within the scope of madrasah schools, the implementation of regulation was also disseminated to teachers and also school committees conducted by the leadership or Vice Principal III in the field of madrasah education facilities and infrastructure.

\section{b) Clarity}

Clarity of information in the implementation of government regulation no.24 of 2007 occurred because the implementers in each work unit formulated a common vision and mission in the implementation of the regulation. The formulation of the vision and mission of implementing the regulation gave birth to clarity related to the implementation of the regulation. As proof of the clarity of the submission of government regulation no. 24 of 2007 and its top-down implementation agenda, it can be seen from the achievements of the accreditation of madrasah in Medan City which already has accreditation A.

\section{c) Consistency}

The socialization activities, workshops, and technical guidance on government regulation no.24 of 2007 organized by the North Sumatra Ministry of Religion in the field of madrasa education to the heads of madrasah or Vice principal III in the field of facilities and infrastructure have been carried out consistently since 2009. However, in 2019 the socialization, training, and technical guidance for the implementation of infrastructure are not specifically carried out in one activity. This is caused by two main factors that are interrelated with one another, namely first, the agenda of the North Sumatra Ministry of Religion in the field of madrasah education is focused on the development and improvement of the madrasa curriculum, second, the limited DIPA budget to carry out these activities. Even so, efforts to build communication related to the implementation of the regulation continue to be carried out through work meetings and discuss of leaders and work units as implementers.

\section{Readiness of Supporting Resources for Policy Implementation \\ a) Human Resources}

The task and responsibility of implementing rules of Minister of Education Regulation number 24 of 2007 is carried out by the implementers at each level. At the provincial level there is the North Sumatra Ministry of Religion's Regional Office, particularly in the field of madrasah education in terms of facilities and infrastructure, as the party that has functions, duties and responsibilities in relation to the implementation of government regulation no. 24 of 2007 in madrasah at the district/city level. Whereas within the scope of state-owned Islamic schools in Medan there are Vice principal III in the field of facilities and infrastructure that function, task and are responsible for the process of implementing the rgeulation.

\section{a) Information}

Information related to the implementation of government regulation no.24 of 2007 in state-owned madrasah in Medan, there are two mechanisms for delivering information, namely hierarchical and non-hierarchical. First, hierarchically; Hierarchical information model is a top-down information model (from superiors to subordinates) and bottom-up (from bottom to 
top). In this context the information model is top-down, information on the implementation of government regulation no. 24 of 2007 is based on information from the Head of the North Sumatra Ministry of Religion, to the head of madrasa education sector, to the head of facilities and infrastructure section and then to the head of madrasah and staff. While information is bottomup (from bottom to top) is information that appears from subordinates. This is because subordinates get new information related to the implementation of the regulation. Second, nonhierarchical information; in this context, implementers at the level of facilities and targets in the madrasah education sector and Vice principal in the infrastructure and facilities in madrasah generally take the initiative to seek information to add, clarify, and understand the implementation agenda for government regulation no. 24 of 2007.

\section{b) Authority}

Authority (authority) is legitimacy for the implementers of the policy (implementer) that is formal. First, is in the North Sumatra Ministry of Religion. In the institutional structure in the North Sumatra Ministry of Religion there is a work field, namely the madrasa education sector. In the field of madrasa education there are work units that are specifically related to facilities and infrastructure, namely the facilities and infrastructure section. Second, is in the madrasah environment. In the bureaucratic structure in Madrasah in Medan, the headmaster is given the authority to appoint and place 1 Deputy Head of Madrasah (WKM) in the field of facilities and infrastructure, generally called Vice Principal III. Vice principal III in the field of facilities and infrastructure is a functional position based on SK (Certificate) as a form of legality of his position.

\section{c) Budget Resources}

In the implementation of government regulation no.24 of 2007 concerned on facilities and infrastructure in Medan City Madrasas, there are two budgets, namely: First, the DIPA fund budget of the Ministry of Religion is the budget of the government that is handed down to madrasah through the North Sumatra Ministry of Religion in the Field of Madrasah Education, Madrasah Education. Second, madrasa committee funds are sourced from grants or donations from parents / guardians of students. The parents / students give a sum of grant money ordonations.

\section{d) Equipment / Facilities Resources}

The availability of supporting facilities for the implementation of Permendiknas number 24 of 2007 and a mandatory requirement for the implementer is a set of computers or laptops and printer machines, in addition to desks, rooms and others that have become facilities that must exist in every agency / institution. The computer or laptop functions as a medium for input of facility and infrastructure data into the Infrastructure Management Information System (SIMSARPRAS) application, and the Electronic Monitoring and Evaluation of Madrasah Facility and Infrastructure Assistance (E-MONEV) applications. This application is a non-physical supporting facility. Through this application, the parties concerned, especially the facilities and infrastructure section of the madrasah education sector of the North Sumatra Ministry of Religion, can find out the achievements of the facilities and infrastructure based on the standards specified in government regulation no.24 of 2007.

\section{Disposition of Policy Implementation}

Disposal of policy implementation requires two main factors, namely the appointment of bureaucracy and the provision of incentives. 


\section{a) Appointment of Bureaucracy}

In the implementation of Minister of Education number 24 of 2007, there is a separated mechanism in the North Sumatra Ministry of Religion and the MAN in Medan City in selecting and appointing people as implementers. Within the North Sumatra Ministry of Religion's Regional Office, the Head of Madrasah Education has the authority to appoint the section head of madrasah facilities and infrastructure. Where in the madrasah environment, the madrasah head has the authority to appoint WKM III in the area of madrasah facilities and infrastructure as well as its operator staff.

\section{b) Incentives}

In carrying out the duties and responsibilities related to the implementation of Minister of Education Regulation number 24 of 2007 there are incentives given to implementers. Within the scope of madrasas, WKM III in the field of facilities and infrastructure as well as incentive operator staff are fully provided by the madrasah head that comes from DIPA funds. DIPA funds provided by the North Sumatra Ministry of Religion are then allocated as incentives based on school principal approval.

\section{Bureaucratic Structure in Policy Implementation}

Bureaucratic structure in policy implementation relates to 2 main characteristics, namely operational forced (SOP) standards and the division of responsibilities.

\section{a) Implementation Manual or Operational Procedure (SOP) Standards}

The SOP on the technical implementation of government regulation no.24 of 2007 was not / not yet formulated by the North Sumatra Ministry of Religion in the Field of Madrasah Education, but the effort to implement and also manage facilities and infrastructure was based on the workflow mechanism determined in each field. This workflow is formed based on the division of tasks and responsibilities in each area of the work unit. In State Madrasah Aliyah in Medan City, the technical SOP on the implementation of the regulation was also not/not yet formulated. Matters related to the implementation of the implementation of madrasa facilities and infrastructures are adjusted directly to the contents of government regulation no.24 of 2007 .

\section{b) Division of Responsibilities}

In the organizational structure in the North Sumatra Ministry of Religion there are several fields that have their respective duties and functions, one of which is the madrasa education sector. Within the scope of the madrasa education sector there are 5 sections and 1 group of functional positions, namely the curriculum and evaluation section, the educator and teaching staff section, the facilities and infrastructure section, the student section, the institutional section and the madrasa information system. The implementation of the policy on state-owned aliyah madrasa infrastructure in the city of Medan is responsible for the facilities and infrastructure section of the madrasah education sector of the North Sumatra Ministry of Religion. While within the scope of state madrasas in Medan, the duties and responsibilities related to the implementation of government regulation no.24 of 2007 and management of educational facilities and infrastructure are carried out by Deputy Head of Madrasah III in the field of facilities and infrastructure.

\section{Conclusion}

The implementation of The Minister of National Education Regulation Number 24/2007 conducted by state madrassas in Medan cannot be separated from the role of the Regional 
Office of the Ministry of Religion of North Sumatra Province (North Sumatra Ministry of Religion) through the Sector of Madrasah Education in the facilities and infrastructure section. In this context the Madrasah Education Sector facilities and infrastructure section conducts guidance, coordination and work meetings related to the implementation of government regulation no.24 of 2007. Implementation of these regulations has been carried out from 2009.

Synergy between work units in implementing Minister of National Education Regulation Number 24/2007 has been based on the elements of implementation that include the dimensions of communication. Availability of supporting resources, disposition of policy implementation in the form of bureaucratic appointment and provision of incentives, and division of work tasks based on mechanism / work flow between each work unit. So that MAN education facilities and infrastructures in Medan City reach the standards determined by Minister of Education Regulation No.24 of 2007.

\section{References}

[1] Purwanto, Erwan Agus dan Dyah Ratih Sulistyastuti. Implementasi Kebijakan Publik: Konsep dan Aplikasinya di Indonesia. Yogyakarta: Gava Media (2012).

[2] Subarsono. Analisis Kebijakan Publik Konsep Teori dan Aplikasi. Yogyakarta: Pustaka Pelajar Tangkilisan, Hessel Nogi S. 2007. Manajemen Publik. Jakarta: Grasindo. (2009).

[3] Ripley, Ronald B and Grace Franklin. Policy Implementation Bereaucracy. Chicago: Dorsey Press Subari. 1994. Supervisi Pendidikan. Jakarta: Bumi aksara. (1986).

[4] Abdul Wahab, Solichin. Analisis Kebijakan : Dari Formulasi ke Implementasi Kebijakan Negara Edisi Kedua. Jakarta: Bumi Aksara. (2008).

[5] Abdul Wahab, Solichin. Analisis Kebijakan dari formulasi ke implementasi kebijakan Negara. Jakarta: Bumi Aksara. (1991).

[6] Arikunto,S. Prosedur Penelitian Suatu Pendekatan Praktik. Jakarta: Rineka Cipta. (1993).

[7] Budi Winarno, Teori dan Proses Kebijakan Publik, Yogyakarta: Media Pressindo. (2002).

[8] Daryanto, M. Administrasi Pendidkan, Jakarta: Rineka Cipta. (2006).

[9] Departeman Pendidikan Nasional. Kamus Besar Bahasa Indonesia. Jakarta: Balai pustaka. (2008).

[10] Ibrahim, Bafadal. Manajemen perlengkapan sekolah: teori dan aplikasinya. Jakarta: Bumi Aksara. (2008).

[11] Mulyasa. Manajemen Berbasis Sekolah, Konsep, Strategi dan Implementasi. Bandung: Remaja Rosdakarya. (2004).

[12] Nana, Syaodih. Pengembangan Kurikulum, Bandung: Remaja Rosda Karya. (2009)

[13] Nawawi, Hadari. Administrasi Sekolah. Jakarta : Ghalia Indonesia. (2001)

[14] Permendiknas Republik Indonesia. Number 24 Tahun 2007 tentang: Standar Sarana dan Prasarana diperuntukan Sekolah Dasar/ Madrasah Ibtidaiyah (SD/MI), Sekolah Menengah Pertamal Madrasah Tsanawiyah (SMP/MTs), dan Sekolah Menengah Atas/Madrasah Aliyah (SMA/MA).

[15] Tilaar, H.A.R dan Riant Nugroho. Kebijakan Pendidikan. Yogyakarta: Pustaka Pelajar. (2008) 